\title{
SAPROXYLIC BEETLE ASSEMBLAGES IN OSIJEK PARKS
}

\section{Nataša Turić, Matej Šag, Kristina Kljajić, Denis Deže, Katarina Batrnek, Dragana Bjelovuk}

\author{
Department of Biology, Josip Juraj Strossmayer University, Ulica cara Hadrijana 8A, 31000 Osijek, Croatia \\ (e-mail: nturic@biologija.unios.hr)
}

Turić, N., Šag, M., Kljajić, K., Deže, D., Batrnek, K. \& Bjelovuk, D.: Saproxylic beetle assemblages in Osijek parks. Nat. Croat. Vol. 28, No. 1.,89-98, Zagreb, 2019.

A study was carried out in two parks, Perivoj kralja Tomislava and Perivoj kralja Petra Krešimira IV, in the period from June to August 2017. In all, 26 saproxylic beetle species listed in 14 families were identified. From these, three species are listed in the European Red List of Saproxylic beetles, two species as least concern and one as near threatened according to the IUCN. The family Nitidulidae was the most abundant followed by Curculionidae, Elateridae, Carabidae and Tenebrionidae. According to the Sørensen index, a similarity between these two locations was established depending on the beetle fauna present. This research showed the presence of E. ferrugineus in urban parks.

Key words: abundance, habitat, endangerment, Elater ferrugineus, urban area

Turić, N., Šag, M., Kljajić, K., Deže, D., Batrnek, K. \& Bjelovuk, D.: Saproksilni kornjaši u parkovima grada Osijeka. Nat. Croat. Vol. 28, No. 1., 89-98, Zagreb, 2019.

Istraživanje je provedeno na području dvaju parkova, Perivoja kralja Tomislava i Perivoja kralja Petra Krešimira IV u razdoblju od lipnja do kolovoza 2017. godine. Ukupno je uzorkovano 26 vrsta saproksilnih kornjaša svrstanih unutar 14 porodica. Tri vrste se nalaze na Europskoj crvenoj listi saproksilnih kornjaša, dvije od njih su označene kao najmanje zabrinjavajuće dok je jedna na temelju kategorija ugroženosti, gotovo ugrožena. Najbrojnija je bila porodica Nitidulidae, potom Curculionidae, Elateridae, Carabidae i Tenebrionidae. Na temelju Sørensenovog indeksa utvrđena je sličnost između dvije istraživane lokacije obzirom na utvrđenu faunu kornjaša. Istraživanjem je utvrđena prisutnost vrste E. ferrugineus u gradskim parkovima.

Ključne riječi: raznolikost, stanište, ugroženost, Elater ferrugineus, gradsko područje

\section{INTRODUCTION}

Beetles (Coleoptera) are the largest insect order with over 400000 described species (New, 2010). Saproxylic beetles are present in almost all terrestrial ecosystems where they occupy a diverse and very important ecological niche (Dražina \& Temunović, 2011) such as dead and/or dying trees. They are one of the most endangered ecological groups of beetles in Europe (NIETO \& AlEXANDER, 2010; Aтау et al., 2012). The importance of these insects is in their linking of various stages of trophic chains. Their distribution is correlated with the stage of their habitat. They are an important food source for birds and small mammals, and together with fungi they are involved in the fragmentation and destruction of dead wood (CARPANETo et al., 2010). 
In urban parks there may be trees of all stages that are commonly suitable habitats for saproxylic beetles. Although, in order to preserve the aesthetic and cultural value of the parks, older trees should be left since they provide a source of shade, parks are traditionally managed and dead wood is often removed because it may represent a public safety hazard (DrAžINA et al., 2012). Thus by common practices in urban parks, suitable habitats for saproxylics are scarce, which greatly reduces the diversity and abundance of their populations.

A similar study related to an old city park was conducted in Maksimir Park in Zagreb and recorded 850 specimens of beetles, divided into 27 families, Cerambycidae and Cetoniidae being the most common (DražIna \& Temunović, 2011). Over 60 different beetle species were identified, out of $w$ hich16 were on the European Red List of Saproxylic Beetles. Within that study a stable population of NATURA 2000 species, Cerambyx cerdo and Lucanus cerous was established (DrAŽınA et al., 2012).

Entomological studies on saproxylic fauna in Osijek parks had not been conducted hitherto. The aim of this study was to provide an insight into saproxylic beetle diversity in the researched parks. And additional purpose of the study was to obtain the presence of endangered species.

\section{MATERIAL AND METHODS}

\section{Study site}

The research was conducted in Osijek, in two parks (Fig. 1). Perivoj kralja Tomislava, with area of $45,450 \mathrm{~m}^{2}$ is the biggest, oldest and the most valuable one and has had protected status since 1973 as a natural monument. This park has had its name changed several times (Jukić, 1996). In 1958 there were 104 species of trees and shrubs determined (GUCUNSKI, 2002). The eastern area of the park is a large lawn with patches of maple (Acer saccharinum L.) and a playground on the

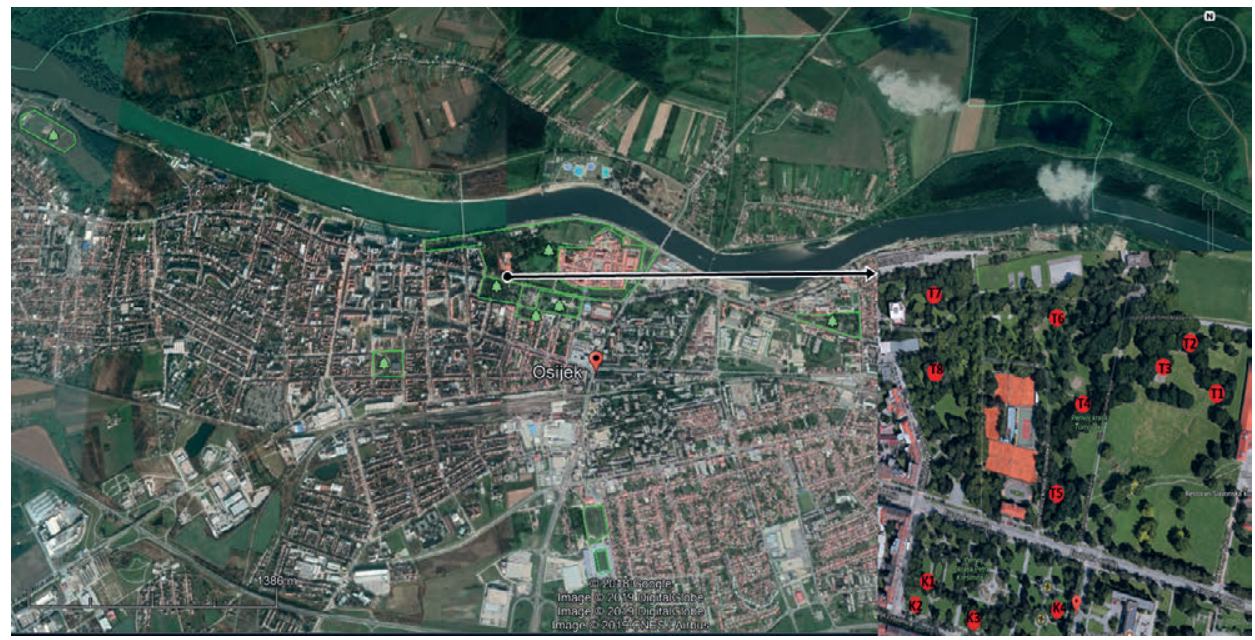

Fig. 1. Map of Osijek and surrounding area (parks are marked green). Right bottom is a detail of researched area (T1 - T8 Perivoj kralja Tomislava, K1 - K4 Perivoj kralja Petra Krešimira IV) 
northwestern part. The Kentucky coffeetree (Gymnocladus dioicus C. Koch) and black walnut (Juglans nigra L.) stands are considered to be the oldest in the park. Some of the native tree species are hornbeam (Carpinus betulus L.), ash (Fraxinus excelsior L.), black pine (Pinus nigra J. F. Arnold), beech (Fagus sylvatica L.), alder (Alnus glutinosa (L.) Gaertn.), rows of horse chestnut (Aesculus hippocastanum L.), lime (Tilia sp.) and the oak (Quercus robur L.) with a girth of 4 meters. There are also bushes of holly (Ilex aquifolium L.). Among the oldest trees in this park there are a few specimens of F. excelsior with a girth of $3.5-4$ meters, white mulberry (Morus alba L.) with a girth of 2.5 meters, bean tree (Gleditschia triacanthos L.) with girth of $2.5-3$ meters and a height of 25 meters. Tilia tomentosa is more abundant than T. cordata (Gucunski, 2002).

Perivoj kralja Petra Krešimira IV is organized in the French style and divided into three geometric sections including conifers, deciduous trees and rose bushes within an area of 24,200 $\mathrm{m}^{2}$. In 1958 there were 65 tree and shrub species (GUCUNSKI, 2002). The park has a four-line alley of great maple (Acer pseudoplatanus L.), grassy areas and box trees (Buxus sempervirens L.). It has an alley of rose bushes (Prunus cerasifera Ehrh. and P. serratus var. Hisakura). There are representatives of Ginkgo biloba L., Pinus strobus L., Cornus mas L., Acer campestre L. and an alley of English oak (Q. robur var. fastigiata) (GUCUNSKI, 2002).

Sampling was performed from June to August, 2017. Eight traps were placed in Perivoj kralja Tomislava and four traps were placed in Perivoj kralja Petra Krešimira IV. Traps in the parks were marked because there are plenty of people with children, cyclists, joggers and workers who maintain the parks. We used window flight-intercept traps (cross-vanes) consisting of two transparent plexiglas panels $(17 \mathrm{~cm} \times 49 \mathrm{~cm})$ cut out in a rectangular shape (Fig. 2) according

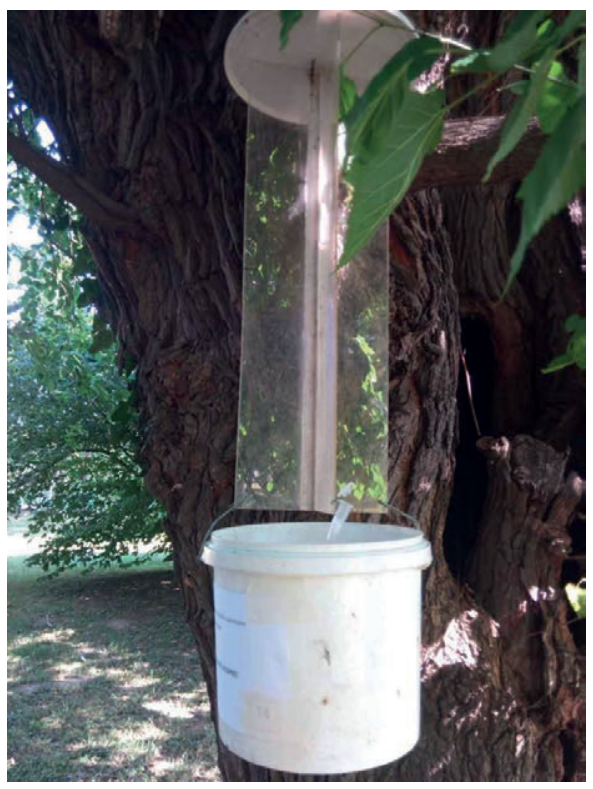

Fig. 2. Flight intercept trap (cross-vanes) to Ranius \& Jansson (2002). The top side plates were tied to the lid and on the underside they were attached to the plastic container. The traps were tied to a branch at a height of approximately $150 \mathrm{~cm}$. The containers were filled with vinegar as well as detergent to reduce the surface tension of the liquid. (R)(+)- $\gamma$-decalactone, a male-released sex pheromone of Osmoderma eremita was used to determine the presence of O. eremita and Elater ferrugineus. The pheromone is known to attract females of E. ferrugineus (LARsson et al., 2003; Zauli et al., 2014). We put $500 \mu \mathrm{L}$ of pheromone in small vial attached to the plexiglas panel. Samples were collected every 7 days, stored in labelled plastic containers filled with vinegar. All samples were determined using determination keys Freude et al. (1969; 
1971), Baraud (1992), Bense (1994) and a systematic list of species was created using the online database Fauna Europaea (DE Jong et al., 2014). All samples were stored in a collection at the Josip Juraj Strossmayer University of Osijek, Department of Biology.

\section{RESULTS}

A total of 26 species were determined, classified into 14 families (Tab. 1). Twenty five species (330 individuals) were sampled in the Perivoj kralja Tomislava and eight species (38 individuals) in Perivoj kralja Petra Krešimira IV.

During June we collected the largest representation of saproxylic beetles (227 individuals, 15 species), in July the number of individuals was reduced to 118 , or 18 species. In August we collected only 23 individuals (5 species) (Fig. 3, Fig. 4). Three species were included in the IUCN European Red List of Saproxylic beetles.

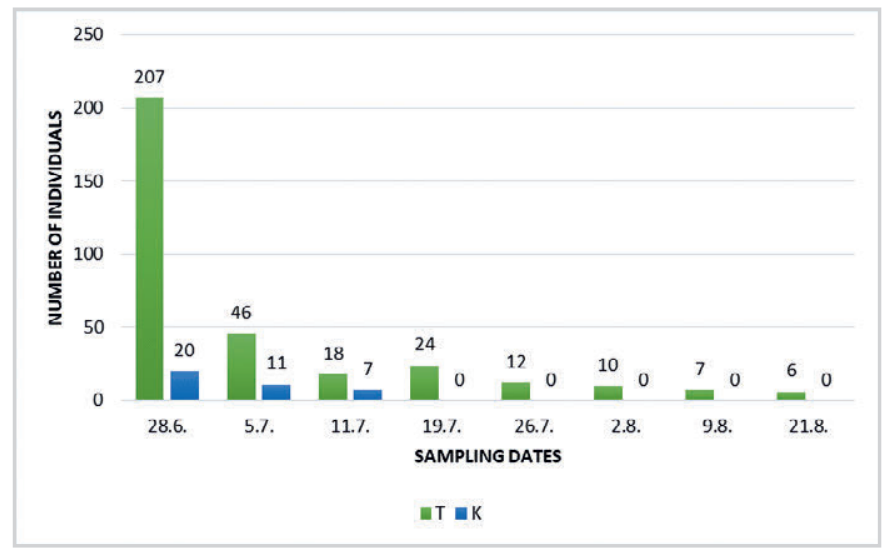

Fig. 3. Number of individuals within the sampling dates (T - Perivoj kralja Tomislava, K - Perivoj kralja Petra Krešimira IV)

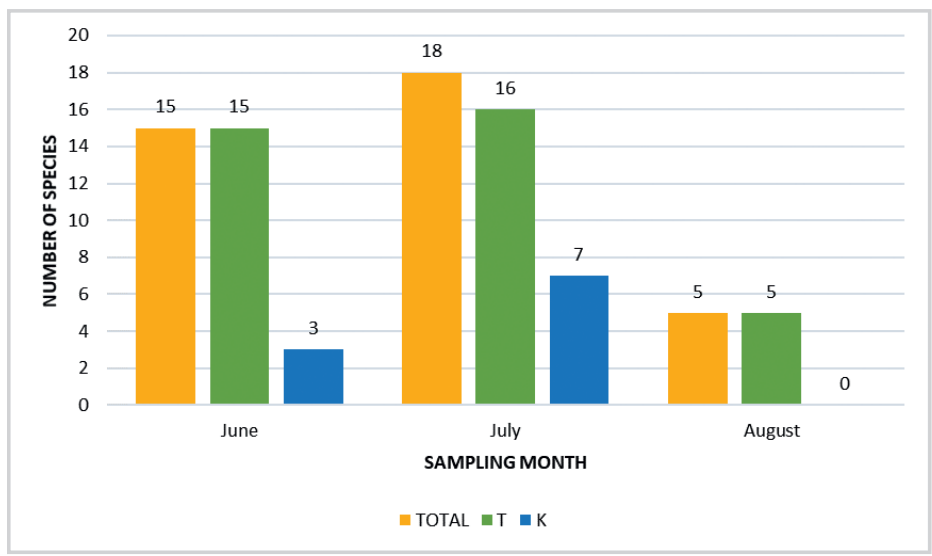

Fig. 4. Number of species within the sampling months (Legend: TOTAL shows total number of species collected on both sites, T shows Perivoj kralja Tomislava, K shows Perivoj kralja Petra Krešimira IV) 
Tab. 1. List of saproxylic beetles at two sampling sites with number of captured individuals.

\begin{tabular}{|c|c|c|c|}
\hline Family & Species name & $\begin{array}{l}\text { Perivoj kralja } \\
\text { Tomislava }\end{array}$ & $\begin{array}{l}\text { Perivoj kralja } \\
\text { Petra Krešimira IV }\end{array}$ \\
\hline \multicolumn{4}{|l|}{ Anobiidae } \\
\hline & $\begin{array}{l}\text { Hadrobregmus denticollis (Creutzer in Panzer, } \\
\text { 1796) }\end{array}$ & 0 & 1 \\
\hline \multicolumn{4}{|c|}{ Buprestidae } \\
\hline & Agrilus biguttatus (Fabricius, 1776) & 1 & 0 \\
\hline \multicolumn{4}{|l|}{ Carabidae } \\
\hline & Dromius quadrimaculatus (Linne, 1758) & 2 & 0 \\
\hline & Harpalus affinis (Schrank, 1781) & 1 & 0 \\
\hline & Leistus ferrugineus (Linneaeus, 1758) & 5 & 0 \\
\hline & Nebria brevicollis (Fabricius, 1792) & 2 & 0 \\
\hline \multicolumn{4}{|c|}{ Cerambycidae } \\
\hline & Strangalia attenuata (Linnaeus, 1758) & 1 & 0 \\
\hline \multicolumn{4}{|c|}{ Coccinellidae } \\
\hline & Coccinella septempunctata Linnaeus, 1758 & 1 & 0 \\
\hline \multicolumn{4}{|c|}{ Chrysomelidae } \\
\hline & Psylliodes chrysocephala (Linnaeus, 1758) & 7 & 2 \\
\hline \multicolumn{4}{|c|}{ Curculionidae } \\
\hline & Dorytomus tortrix (Linnaeus, 1761) & 1 & 0 \\
\hline & Phyllobius viridearis (Laicharting, 1781) & 1 & 0 \\
\hline & Poophagus sisymbrii (Fabricius, 1776) & 8 & 1 \\
\hline \multicolumn{4}{|l|}{ Dasytidae } \\
\hline & Aplocnemus chalconatus (Germar, 1817) & 1 & 0 \\
\hline \multicolumn{4}{|l|}{ Elateridae } \\
\hline & Dalopius marginatus (Linnaeus, 1758) & 2 & 0 \\
\hline & Elater ferrugineus Linnaeus, 1758 & 4 & 1 \\
\hline & Melanotus villosus (Fourcroy, 1785) & 2 & 2 \\
\hline \multicolumn{4}{|l|}{ Erotylidae } \\
\hline & Triplax russica (Linnaeus, 1758) & 3 & 0 \\
\hline & Triplax sp. Herbst, 1793 & 1 & 0 \\
\hline \multicolumn{4}{|l|}{ Histeridae } \\
\hline & Eblisia minor (Rossi, 1792) & 2 & 0 \\
\hline & Paromalus flavicornis (Herbst, 1792) & 1 & 0 \\
\hline \multicolumn{4}{|l|}{ Nitidulidae } \\
\hline & Cryptarcha strigata (Fabricius, 1787) & 5 & 1 \\
\hline & Glischrochilus quadriguttatus (Fabricius, 1776) & 262 & 29 \\
\hline & Nitidula rufipes (Linnaeus, 1767) & 7 & 0 \\
\hline \multicolumn{4}{|c|}{ Staphylinidae } \\
\hline & Ocypus olens (O. Muller, 1764) & 1 & 0 \\
\hline \multicolumn{4}{|c|}{ Tenebrionidae } \\
\hline & Prionychus ater (Fabricius, 1775) & 8 & 1 \\
\hline & Tenebrio obscurus Fabricius, 1792 & 1 & 0 \\
\hline \multicolumn{2}{|l|}{ In total } & 330 & 38 \\
\hline
\end{tabular}


The family Nitidulidae was the most abundant with 304 individuals sampled (82.6\%) and 3 species of which the largest number of individuals (291) were of Glischrochilus quadrisignatus while Nitidula rufipes contributed 7 individuals and Cryptarcha strigata 6 individuals. Both the Curculionidae and the Elateridae family provided 11 individuals $(2.98 \%, 3$ species each). Within the family Curculionidae Poophagus sisymbrii was present with 9 individuals. Elater ferrugineus (Elateridae) was present with 5 individuals. Carabidae and Tenebrionidae were both present with 10 individuals each (2.71\%), Carabidae with 4 species, of which Leistus ferrugineus present with 5 individuals. Tenebrionidae were represented by 2 species and Prionychus ater by 9 individuals. From the family Chrysomelidae there was only one species, Psylliodes chrysocephala with 9 individuals (2.44\%). Other families were recorded with less than $2 \%$ of the total number of individuals (Fig. 5).

The Sørensen index showed the two sites had a $24.13 \%$ similarity and 7 species in common.

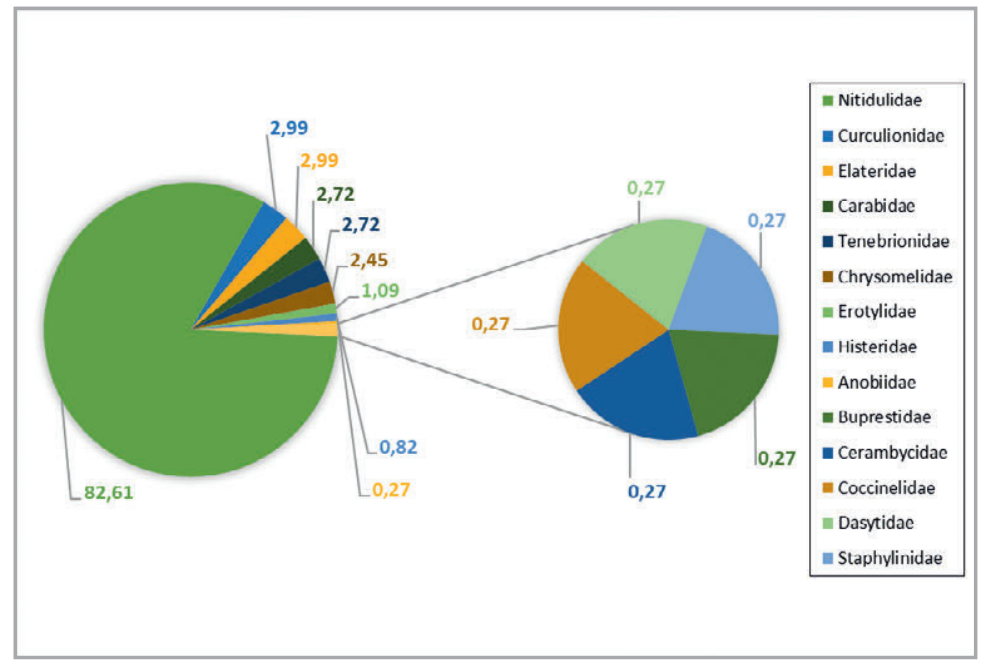

Fig. 5. Percentage contribution of individuals within the families

\section{DISCUSSION}

Environmental diversity, quality and preservation can be estimated by the abundance of saproxylic beetles, which are globally widespread (KoROTYAEv, 2006). Ecological traits and anthropogenic factors can have severe influences on saproxylic beetle diversity. The research location comprises green areas in an urban zone and it is under anthropogenic influence that continuously alters the natural state of the environment. However, research has shown that green areas such as parks can be important biological hotspots for saproxylic beetles (DražIna \& Temunović, 2011). Despite the alteration of the natural environment, in the present study, 26 species of saproxylic beetles were detected that had found favorable niches in an urban zone. Although the two areas were close to each 
other, they differed in their saproxylic beetle communities, which shows how different tree arrangement and diversity have an impact on saproxylic beetles. They have only 7 species in common and this is because the Perivoj kralja Tomislava has larger area and bigger tree composition in species and individuals. Thereare also more veteran trees that provide suitable microhabitats for a variety of invertebrates including saproxylic beetles. Density, formation and tree species composition create a microclimate (temperature, light, humidity) that is favorable for saproxylic beetles. The four-spotted sap beetle, Glischrochilus quadrisignatus was most frequent species in this research in both of the parks (291 individuals). It feeds generally on fruits and other plant parts that are decomposing (KeszTHeLYI, 2012).

Of great interest was the Elateridae family with E. ferrugineus, listed in the IUCN European Red List of Saproxylic beetles (CÁlix et al., 2018). E. ferrugineus has the largest body size in Central Europe and is one of the most visibly attractive click beetles. It is a rare species throughout its entire distribution, which ranges from Spain to the Caucasus, and from Italy to Sweden (LAIBner, 2000). In Central Europe, E. ferrugineus is regarded as an "Urwald relict species", a species associated with primeval forest structures and features (Müller et al., 2005; LARsson \& MilberG, 2014) and it is used in landscape ecology as an indicator species for old and species-rich deciduous forests (Schmidl \& Bussler, 2004). In this study, Perivoj kralja Tomislava is shown to have a composition of veteran trees that provide wider microhabitats for beetles, and this could be why E. ferrugineus was found within it. This is the only recent finding of this species since Minaljević et al., (1999). However, this finding is rather doubtful because it was impossible to find the reference Pančić (1987) since it is missing in the list of references in the work Minaljević et al. (1999) where the species is mentioned as present according to research in the area of Kopački rit Nature Park, in the eastern part of Croatia, $13 \mathrm{~km}$ from the study site. For this species and other saproxylic organisms it is very important to leave old trees, stumps and logs and thus preserve suitable microhabitats for them because fragmentation can lead to the risk of population decline and of the extinction of these populations (DrAžInA \& TEMUnović, 2011).

I The majority of studies were focused on the protection of woods and nature that are not subject to anthropogenic intervention, because that type of habitat is considered a biological hotspot (VRŠKA et al., 2001). However, we showed in our research that green areas in urban zones can also potentially provide suitable environments for assemblages of saproxylic beetles.

\section{CONCLUSION}

With this research in the area of Perivoj kralja Tomislava and Perivoj kralja Petra Krešimira IV, which was conducted in the period from June to August 2017, we sampled 26 species of saproxylic beetles and 367 individuals, 328 individuals of which were recorded in area of Perivoj kralja Tomislava. The largest occurrence of saproxylic beetles was recorded in June. The most abundant species was Glischrochilus quadrisignatus. There were some similarities of the fauna in the two 
explored parks according to Sørensen's similarity index. This research showed the presence of E. ferrugineus in urban parks.

\section{ACKNOWLEDGMENTS}

This research was supported by Department of Biology, Josip Juraj Strossmayer University and is part of the project "Students in science". We thank our colleagues from the Natural Institute of Biology, Slovenia who provided for this research the pheromone ${ }^{\circledR}-\gamma$-decalactone and expertise that greatly assisted the research.

\section{REFERENCES}

Received August 6, 2018

Atay, E., Jansson, N. \& Gürkan, T., 2012: Saproxylic beetles on old hollow oaks (Quercus spp.) in a small isolated area in southern Turkey. Zoology in the Middle East 57, 105-114.

BARAud, J., 1992: Coléoptères Scarabaeoidea d'Europe. Faune de France et Régions Limitrophes 78. Lyon, Fédération française des Sociétés de Sciences naturelles et Société linnéenne deLyon.

Bense, U., 1994: Longhorn beetles. Illustrated Key to the Cerambycidae of Europe. Verlag Josef Margraf. pp. 513.

Cálix, M., Alexander, K. N. A., Nieto, A., Dodelin, B., Soldati, F., Telnov, D., Vazquez-Albalate, X., Aleksandrowicz, O., Audisio, P., Istrate, P., Jansson, N., Legakis, A., Liberto, A., Makris, C., Merkl, O., Mugerwa Pettersson, R., Schlaghamersky, J., Bologna, M. A., Brustel, H., Buse, J., Novák, V. \& Purchart, L., 2018: European Red List of Saproxylic Beetles. Brussels, Belgium: IUCN. Available at: http://www.iucnredlist.org/initiatives/europe/publications

Carpaneto, G. M., Mazziotta, A., Coletti, G., Luiselli, L. \& Audisio, P., 2010: Conflict between insect conservation and public safety: the case study of a saproxylic beetle (Osmoderma eremita) in urban parks. Journal of Insect Conservation 14, 555-565.

DražınA, T. \& Temunović, M., 2011: Istraživanja ciljnih Natura 2000 vrsta kornjaša u parku Maksimir. Konačni izvještaj. Udruga za biološka istraživanja - BIOM, Zagreb. pp. 24.

DražınA, T., Temunović, M. \& Šerić JelaskA, L., 2012: Saproksilna zajednica kornjaša starih gradskih parkova: primjer iz parka Maksimir (Zagreb, Hrvatska). 11. Hrvatski biološki kongres, kongresno priopćenje. Šibenik. p. 79-80.

DE Jong, Y. et al., 2014: Fauna Europaea - all European animal species on the web. Biodiversity Data Journal 2: e4034. doi: 10.3897/BDJ.2.e4034.

Freude H., Harde K. W. \& Lohse G. A., 1969: Die Käfer Mitteleurons, Band 8. Teredilia, Heteromera, Lamellicornia. Goecke \& Evers Verlag, Krefeld. Germany.

Freude H., Harde K. W. \& Lohse G. A., 1971: Die Käfer Mitteleurons, Band 3. Adephaga2, Palpicornia, Histeroidea, Staphylinoidea 1. Goecke \& Evers Verlag, Krefeld. Germany.

Gucunski, D., 2002: Osječki perivoji i drvoredi, Državni arhiv, Osijek, pp. 119.

Jukıć, T., 1996: Perivoj kralja Tomislava u Osijeku. Prostor: znanstveni časopis za arhitekturu i urbanizam 4, 61-78.

Keszthelyi, S., 2012: Evaluation of flight phenology and number of generations of the four-spotted sap beetle, Glischrochilus quadrisignatus in Europe. Bulletin of Insectology 65 (1): 9-16.

Korotyaev B. A., 2006: A review of the weevil genus Rhinoncomimus Wagner (Coleoptera: Curculionidae: Ceutorhynchinae). Entomologische Abhandlungen 63 (1-2), 99-122.

LAibner, S., 2000: Elateridae of the Czech and Slovak Republics. Kabourek, Zlin.

Larsson, M. C., Hedin, J., Svensson, G. P., Tolasch, T. \& Francke W., 2003: Characteristic odor of Osmoderma eremita identified as a male-released pheromone. Journal of Chemical Ecology 29, 575587.

Larsson, M. C. \& Milberg, P., 2014: High-accuracy sampling of saproxylic diversity indicators at regional scales with pheromones: The case of Elater ferrugineus (Coleoptera, Elateridae). Biological Conservation 171, 156-166.

Mihaljević, M., Getz, D., Tadić, Z., Živanović, B., Gucunski, D., Topić, J., Kalinović, I. \& Mikuska, J., 1999: Zaštita Kopačkog rita. Kopački rit-pregled istraživanja i bibliografija (ur. J. MarTinčıć), 133-139, Hrvatska akademija znanosti i umjetnosti, Osijek. pp. 188. 
Müller, J., Bussler, H., Bense, U., Brustel, H., Flechtner, G., Fowles, A., Kahlen, M., Möller, G., Mühle, H., Schmidl, J. \& Zabransky, P., 2005: Urwald relict species-Saproxylic beetles indicating structural qualities and habitat tradition. Waldökologie Online 2, 106-113.

New, T. R., 2010: Beetles in Conservation. Wiley-Blackwell, West Sussex, 237 pp.

Nieto, A. \& Alexander, K. N. A., 2010: European Red List of Saproxylic Beetles. Publications office of the European Union, Luxembourg. pp. 46.

Ranius, T. \& Jansson, N., 2002: A comparison of three methods to survey saproxylic beetles in hollow oaks. Biodivers Conserv 11, 1759-1771.

Schmidl, J. \& Bussler, H., 2004: Ökologische Gilden xylobionter Käfer Deutschlands. Naturschutz und Landschaftsplanung 36, 202-218.

VršKa, T., Hort, L., Odehnalová, P., Horal, D. \& Adam, D., 2001: The Boubín virgin forest after 24 years (1972-1996) - development of tree layer. Journal of Forest Science 47, 439-460.

Zauli, A., Chiari, S., Hedenström, E., Svensson, G. P. \& Carpaneto, G. M., 2014: Using odour traps for population monitoring and dispersal analysis of the threatened saproxylic beetles Osmoderma eremita and Elater ferrugineus in central Italy. Journal of Insect Conservation 18, 801-813. 
